\title{
MORPHOLOGY AND TYPOLOGY AS A UNIQUE DISCOURSE OF RESEARCH
}

\author{
A B S T R A C T
}

The article presents the attempt to follow the trail of the connection between the morphological and typological researches in architecture and urbanism. The principles of morphology and typology are noticed as unavoidable for comprehension of the entire context of the discipline of architecture and urbanism. The interaction between architectural typology and urban morphology are particularly emphasized as the most multilayered and most complex form of typological classification. The attention is directed towards stressing the unique morphological typological discourse of theoretical researches and practical implementation in architecture and urbanism, the basic concept of which is to transform the experience gained into a sort of code, which would be the pattern for the new step in further transformation of architectural and urban elements of the urban spaces in future. 


\section{INTRODUCTION}

Morphological and typological researches, due to the high standard of their scientific and professional competence, provide a fundamental contribution in understanding of the discipline of architecture and urbanism.

Morphology is the area in which key interests, professional and creative potentials are focused, and also the identity of theory and practice of architecture and urbanism. The basic phenomenon and notion for morphology in architecture and urbanism is primarily the synonym for architectural and urban form as the "shell", "tissue"... which finds the home for the social community and its activities, as well as its memory and public values. The built environment, physical structure, spatial entities and ambiances, their functional requirements and possibilities, their aesthetic components and significances as well as the social and cultural identities, are the products of a complex morphogenesis. They have inherited a series of influential factors from ethical and economic to aesthetic and emotional ones, which in times and through history acquire their feature exactly in the physical form of the city, primarily in the form of its public spaces and built structures. Morphological researches combine several methods, first of all comparative analyses of the theoretical sources, notions and practical examples of the urban forms, which are immanent to the morphological theory, namely to the history and theory of the urban planning and design. At the same time, the corresponding methodological tools of the urban history and history of architecture and art are engaged. Thus morphological researches acquire an enviable level of relevance in versatile study of the elements of the urban space, adding to its more complete and richer scientific clarification.

The subject of typology in architecture and urbanism is classification by studying the architectural and urban elements with an objective to notice, single out and group the examples possessing common characteristics, in order to classify them in one defined type. Naturally, it is not only about inventorying the common characteristics, but the research of the very essence of those characteristics. The basic objective of preparation of the typological classification in architecture and urbanism primarily relates to formation of the theoretical support on the basis of understanding the principles and procedures which existed on the occasion of formation of the elements of city spaces through history. At the same time, the concrete objective of typology is related to the possibility of directing the transformation of architectural and urban elements by directing the activities of their planning, designing and 
reconstruction. The sense of typological classification in architecture and urbanism is to transform the experience gained into some sort of code, which would present the pattern for the new step in further transformation of the elements of city spaces in future.

The character of typology need not be connected only to defining the individual types, but also to the relations ruling among them. In this field the interaction between the architectural typology and urban morphology is the most multilayered and most complex form of investigation.

\section{MORPHOLOGICAL RESEARCH DISCOURSE}

The notion of morphology is linked to the coined Greek words morphe (form) and logy (science) and thus could be defined as the science on origin and development of the form. As a pattern of research, morphology makes the integral part of numerous scientific disciplines, and is used also as the method explaining the phenomena and processes connected to the origin of specific forms. For example, in biology ${ }^{1}$, morphological researches deal with the form and structure of living beings, in linguistics ${ }^{2}$ they deal with word structure and form, in philosophy ${ }^{3}$ they deal with the form and structure of the mental and logical historical complexes, in sociology ${ }^{4}$ they deal with material form and structure of society, in culturology ${ }^{5}$ they deal with the form and structure of individual cultures, in physical geography ${ }^{6}$ they deal with the structure and form of the Earth's crust, in the urban geography ${ }^{7}$ they deal with the form and structure of the natural and created factors in space, etc. The essential characteristics of all morphological researches are that the form and structure are observed together, as well as to state the common morphological characteristics of certain elements.

Explaining the significance of geomorphology researches and their relation to geography and geology, Jovan Cvijić names geomorphology as "the independent science which differs from both geography and geology, which deals with the analysis of evolution of the form of the Earth surface and which has its genetic method. ${ }^{8}$ The three key characteristics can be isolated from this definition of geomorphology and which are essential for the morphological researches in general: first, it concerns a scientific discipline and not a descriptive method; second, it concerns a discipline which primarily deals with the analysis of forms; finally, it is a discipline which analyses the form in terms of time continuity. 
The specific aspect of morphological researches in architecture and urbanism lies in observation and study of the city form and structure, particularly its built parts and open spaces: entities, blocks, buildings, streets, squares, parks, offshore areas, etc. The domain of morphology in architecture and urbanism includes a multitude of activities which are concentrated in the urban space. When it concerns the individual urban space elements, the majority of them cannot be isolated from the context - social, geographic or any other one. Any part of the urban space (a building, a block, a square) presents a unique entity, however, at the same time it is also part of the wider environment the integral part of which it makes together with certain genetic properties.

The dominating standpoint in architectural and urban practice is the one stating that the basic task of morphology is to assist in interpretation of the new, created or planned forms of the urban space, as well as to confirm their linkage to the heritage and context. Morphology in architecture and urbanism is the means which enables us to reveal many aspects of the essence of the buildings and open spaces. By means of it we discover the entire sophistication and complexity of the phenomenon of urban elements, starting from those fundamental units, such as the house and plot of land, and as far as the city, being the spatial-physical most sophisticated and complex entity.

Even though the morphological researches within the field of architecture and urbanism have been accepted by the architects and urban planners, the definition of the urban morphology mainly originates from the geographers and planners. Thus Milan Vresk defines urban morphology as "the branch of urban geography studying morphological structure of the city with its three-dimensional characteristics". 9 The morphological structure of the city is understood by him as the spatial arrangement and mutual relation of morphological elements in the urban space, such as: the streets, squares, plots of lands, public spaces, blocks, buildings, etc. The above mentioned elements are characteristic by their specific aspects, such as the density of morphology, size, form, position, appearance, etc. Morphological structure of the city depends to a great extent on the urban plan, manner of city land utilization, significance and distribution of functional parts of the city, historical and contemporary development.

The geographer Robert Dickinson defines urban morphology as "the study of the plan and buildings of the city as seen through its concept, development and function." 10 Two basic groups of researches are considered as the essential by him: morphological studies, whereby planned bases and architecture are 
interpreted through position, plan, growth and use; and comparative morphological studies, in which different samples are comparatively studied on the basis of the origin, growth and function.

As regards the above mentioned, a conclusion may be derived that urban morphology is a scientific discipline dealing with researches of the origin and development of the form of the city.

\section{Principles of morphological researches in architecture and urbanism}

The basic manner of morphological researches is the comparative method, namely comparative analysis which comprises the analysis of the pattern in origination and development of a certain element as well as its identification within the wider context. In the field of architecture and urbanism the comparative study of the forms, conditions and manner of origination of spatial structures of the city present a prevailing methodological procedure. Given that it studies processes, the morphological method is used empirically. It is the means for comparative analysis of certain conditions or phases of development. When it concerns the city entities, the historical stages of development are essential, whereas for the requirements of the general research of the genesis of a single function its forms in different historical periods should be studied, regardless the geographical location. In both cases it concerns the genesis of a single typological form. In contemporary morphological studies the prevailing research is the research of typological characteristics of the structures and genetic code by means of which their development has been historically determined. Thus the key characteristics of the spatial structure - those which most expressively influence and determine the genesis process - are given the significance.

Morphologically orientated studies within architecture and urbanism are characteristic by comprising the triple principle in interpretation of the city morphology and open spaces. On one part the classification of forms dominates, on the other one the identity of the environment, and on the third part the relation between the time and the space.

The first principle of morphological studies in architecture and urbanism is linked to the classification of elements on the basis of not only their form characteristics, but also on the basis of the characteristics of position, size, and 
materials used and other characteristics of structure. The objective of elements classification on the basis of the above mentioned characteristics is dual: on one side, the historical facts are ascertained, namely the procedures and principles which have led to the certain condition; on the other side, the informational basis is determined out of which the ordinances of further development of the observed elements in future may be derived. The fact-orientated analysis alone and classification as per types of forms, geometrical characteristics, dimensions, position or some other physical property is necessary in the research of the spatial forms, however, essentially it is not sufficient. By orientation to the physical characteristics exclusively the field of research is narrowed, and thus the accuracy of the derived conclusions is minimized. To that effect, morphological studies in architecture and urbanism simultaneously deal with the analysis of the functional characteristics of space, in order to determine the causes of origination, emergence of its physical frame.

The second principle of morphological researches in architecture and urbanism is the principle of identity, so that for morphological researches it is necessary to make corresponding adjustments of the objectives and instruments to each individual situation. Each specific situation requires a corresponding project of the research method. General knowledge of historical development, comparisons to other situations in the same time section or analogous examples regardless the time of origination point to the direction of research. Connecting multitude of different facts, conjunctive interpretation of the form and process in space and time, determining key influential factors, habits, cultural standards, forms of communication, relations of different types of space and functions - presents a complex process. The focus of research of the morphology as genetic science besides the form alone also includes the complex processes which have conditioned the origination of that form. Therefore, morphology, more obviously than any other method, uncovers and expresses the social and cultural identity of a certain environment. Each created physical form, in a certain way compresses the history and represents certain culture. For those reasons the spatial forms of the city cannot be fully understood without the knowledge of the social and historical moment, economic status of population, their characteristics, religion, legal norms, and political system. The development of the notion of cultural values and forms is inter-dependent and reciprocal. The purpose of forms changes in time, just as their interpretation changes. Thus it can be deducted that cultural context presents the key generator of the physical characteristics of space, namely that it represents the cultural identity of one community. 
The third principle characteristic for morphological studies from the field of architecture and urbanism is related to the morphogenesis process, which represents a continual and perpetual historical process in which the forms of buildings and open spaces are observed at the time of their emergence, during their development and changes in time. In a way, the morphogenesis processes represent the synthesis of the relation and activity of all actors in an urban structure, resulting in physical forms of space. Morphogenesis represents also the series of space transformations in which its condition is adjusted to the new requirements. Even though the transformation of space alone primarily relates to the change of its form, the causes of changes are equally connected both to the function and to the identity of the environment. Morphogenesis processes may be versatile, depending on the time of emergence and transformation of the cities, their economic structure, functional priorities, culture, etc. Based on the comparative research of the form of urban structures and the historical development of the society, Miloš Bobić classifies morphogenesis processes into non-controlled and controlled ones. ${ }^{11}$

The guidelines for further action in space ensue from the above mentioned principles of morphological studies. The specific characteristic of certain guidelines is reciprocal to the number of interpretations and experiences of morphological researches. That provides an indefinite great number of individual possibilities, bearing in mind that morphology is not a doctrine, but one of the ways of space comprehension.

\section{Historical development of morphological researches in architecture and urbanism}

The development of morphology in architecture and urbanism was contributed to by the theoretical works and practical experiences by means of which this phenomenon has been researched for over a century. A number of different periods are characteristic for the development of morphological researches, out of which each one of them possesses specific qualities according to which it is recognizable.

The origin of morphological researches in architecture and urbanism is linked to the period of the last ten years of the twentieth century, when the first works were written which research architectural and urban spaces. Three German authors: Otto Schluter, Joseph Stubben and Camillo Sitte, in their works dating from that period, can be considered founders of the morphologically orientated researches. The geographer Otto Schluter in his works, particularly in Die 
Siedlungsraume Mitteleropas in fruhgeschichtlicher Zeit ${ }^{12}$ was the first to note the differences between the emergence of the cities in the spontaneous and planned manner on the territory of the present Germany, which in later morphological researches of many authors would prove as one of the key characteristics contributing to the comprehension of the urban spaces. Joseph Stubben in his work Der Stadtebau ${ }^{13}$ presents the most abundant and most comprehensive survey of the form of the cities and their elements until that time, in order to create the frames for interpretation of certain principles of urban spaces developments. They will be exceptionally influential and applicable in later morphological studies. Finally, the historian of art Camillo Sitte in his work Der Stadtebau nach seinen kunstlerischen Grundsatyen ${ }^{14}$ makes a decisive breakthrough which will list this book in line of the most influential morphological studies until now. Namely, Sitte has tried, and in majority of cases has also succeeded, in argument supporting of the reasons which have led to certain morphological characteristics of the elements of the urban space, as well as in classifying typologically the individual elements of the urban spaces into certain categories. There is also a book dating from the beginning of the twentieth century which can be considered as an anthological one in the development of morphology in architecture and urbanism. It concerns the work The American Vitruvius: An Architect's Handbook of Civic $A r t^{15}$ the authors of which being the German planner Werner Hegemann and the American landscape architect Elbert Peets. The very fact that it concerns the two distinguished authors of different vocations and from different cultural regions, suggests the assumption that it is the work which is quite different from the previous ones. Unlike the earlier morphological researches, Civic Art in an adequate way treats also the topics which within the field of architectural and urban morphology have not been studied until then. The authors particularly indicate to the contribution of the civil morale as well as the norms of conduct and manners which have influenced form shaping of the cities. The cultural identity, with its most significant features such as habits, customs, mentality and temperament, is for the first time mentioned as the crucial factor for comprehension of the established forms of the urban space.

In the mid-sixties of the twentieth century, in certain European countries, first in Italy and Spain and later also in Belgium, Germany and France, a group of architects and theoreticians became known as the group of neo-rationalists. The basic characteristics of their work were related to the fact that they expressed the urban spaces by means of the notions of typology and morphology, and that they observed the cities and buildings in historical continuity. The most significant and the most influential among the neo-rationalists was the Italian 
architect Aldo Rossi who in the work L'architettura della citta ${ }^{16}$ emphasized the significance of the historical continuity in morphological researches, as well as the phenomenon of typological study of the elements of the urban spaces. He rejects functionalism as the basic form feature, as thereby the city complexity is denied. According to Rossi, functionalism is not capable of explaining the perseverance of certain forms, when their function changes. The biggest advocates of the typological manner of studying the urban spaces among the neo-rationalists are the Krier brothers, (Leon Krier and Robert Krier), who in many of their theoretical and practical works, such as Urban Space $^{17}$ and The Reconstruction of the European City ${ }^{18}$ emphasized the necessity of typological researches. They have emphasized that architecture and urban culture could only be thus comprehended. The common contribution of the neo-rationalists to the urban morphology is reflected in emphasizing the "type" as the means by which the city can be comprehended. They prefer "type" for the reason that by means of it each element of the urban space can be explained: the square, street, block, borough, colonnade, arcade, etc. The neo-rationalists see "type" dually: directly, as the representative of one category with specific characteristics; and indirectly, as going back and following the model of the architecture and urbanism of the previous periods. Typological cognition of the elements of the urban space is of exceptional importance, because in that way their key characteristics according to which they are recognizable are pointed out.

In mid-eighties of the twentieth century there emerged the movement of the neo-traditionalists, the followers of which found the inspiration for forming of new cities in the principles of development of the cities in the past. Neotraditionalists wished to avoid the negative consequences of the practice of modern urbanism, such as excessive separation of functions and social segregation. For that reason, the accent is placed on providing quality public spaces, which are semi-enclosed, readable and which connect the places used by people. Several new cities which emerged at the end of the eighties and the beginning of the nineties of the twentieth centuries in the United States of America, have attracted great attention of the professional public, since they were built on the basis of the one-of-the-kind urban code, which was prepared by Andres Duany and Elizabeth Plater-Zyberk. Their basic concept was to establish a type of rulebook, which would completely define the construction of the new cities, prescribing all essential architectural and urban elements. That system of rules or codes was named "Traditional Neighborhood Development Ordinance", and according to it a number of cities have already been built, out of which the first and the most famous one is Seaside in Florida ${ }^{19}$, in 1987, for which Leon Krier was the consultant. The basic concept of the above 
mentioned ordinances is in theoretical organization of planning which would be guided by sensible and desired attributes of the traditional neighborhood. The size of the city (Seaside was planned on the area of about 32 hectares) makes it possible to have comfortable pedestrian distances between the place of work and the place of residence, which minimizes the dependence on the car. By reducing the number and duration of car travels, several social objectives have been achieved: leisure time was extended, traffic jams have been decreased, and the soil and fuel have been conserved, namely preserved. The ordinance also adds to the safety of the city as by walking the citizens get to know each other in easier way and establish contacts. Integration of social and age structures become possible due to great number of different types of buildings and functions offered.

The contribution of the neo-traditionalist to the urban morphology is reflected in the fact that they have succeeded in converting the theoretical principles, resulting from the morphological researches of the historical examples, into ordinances, namely codes on the basis of which they have formed new urban structures according to the traditional principles.

\section{TYPOLOGICAL RESEARCH DISCOURSE}

The notion of typology and its cognition in contemporary scientific and research practice provokes various connotations, primarily due to different interpretation of the essence of this notion. There are contradictory positions among the theoreticians and researchers as to whether typology is a scientific discipline, method or only one of the fundamental principles of a particular theoretical methodological approach.

If the term of the notion signifying the subject of the research of that discipline is accepted as the name of the scientific discipline, then, typology can be considered the science on types, given that the notion of typology is linked to the coined Greek words tipos (type, figure, image, trace, form, mould) and $\log y$ (science). In science, in broader sense of the word, typology is assumed to be the discipline which groups the objects and manifestations within one kind according to the type, namely according to the certain characteristics being related.

Contrary to the above, typology, as the form of research, forms the integral part of many scientific disciplines and is used as the method which explains manifestations, processes and phenomena. It can be taken as a totality of general methods and special techniques for solving the issues in identification, 
systematic analysis, synthesis, optimization and other methodological procedures. Perceived in this way, typology is a useful or even essential methodological procedure in research work with the aim of enabling the issues to be solved from within the filed the research is dealing with.

The divergence in the cognition determination of typology in science-method relation imposes the necessity to define this term depending on the context it is applied to, i.e. in relation to the nature of phenomenon and goals of research and study.

Type presents a essential representative of the group, the members of which possess a certain set of features which inter-connect them and at the same time separate them from other groups. A set of features, which has been mentioned above, presents the essence of a type, namely the structure which has been reduced only to the most essential characteristics which distinguish a whole or a group of cases. Possible change of these most significant characteristics would be manifested also on the series of other properties of a particular type.

On the other hand, classification, in the most general sense, presents determining the place of some notion within the system of notions. It concerns mutual linking or separation of elements as per some order or structure, in such way as to define also the elements and their mutual relations. Classification is usually performed in such way to start from the general towards the special (first most general notions are classified, and finally the individual ones), so that gradual breaking down of the notion is carried out, i.e. revealing of its elements. Analysis of a higher notion is carried out through the ladder of lower notions, as far as the desired level or as far as the systematic review of complete structure of that notion. That means that classification comprises first implementation of the analysis procedure and then the synthesis one.

The basic requirement which classification has to meet comes down to the fact that division of one manifestation or notion should be based on its most significant, constituent features, and they are related to the genetic link among manifestations, as well as to the permanent structural manifestation features. However, according to the goal and type of interest, classification of a manifestation may be carried out also as per other, numerous criteria. Each assessment of a certain manifestation is at the same time classification of that manifestation, namely quantitative classification. However, classification is applied also with immeasurable manifestations and that is qualitative classification. ${ }^{20}$ 
Typology is a kind of classification which comprises classification of a series of objects, manifestations and phenomena in several mutually separated groups based on their similarities and differences among key characteristics of the elements they consist of. The presumption of each typology that prominent characteristics related to a series of other characteristics are selected, and that the differences in a key characteristic at the same time presume the difference in the series of other characteristics of the included type. That makes also the basic difference between classification and typology: with classification only one characteristic determines belonging to a class, whereas with typology it concerns a group of key characteristics which define the type. Typologically defined groups are formed by selecting more significant characteristics which make the individual cases of a group mutually related, and different from the cases which belong to some other group.

The individual cases are by means of typology reduced to their essence, and thus determine the principles of their interconnectivity into an entity. Breaking it down to the typical facilitates the explanation of the essence of matters as it excludes less essential particularities.

\section{Forming of Types}

The selection of criteria on the basis of which typological classification is carried out is rather sensitive and responsible activity, because belonging to an individual type is determined on the basis of them. When selecting criteria care must be exercised that the most relevant parameters are selected, as well as that the other ones which are known but were deliberately omitted, cannot influence the classification structure essentially.

The presumption of each typological classification is measurability of its criteria. In a more narrow sense, measurability of criteria can be interpreted as arrangement of the elements of the observed group. Therefore care has to be taken whether the values within each criterion may be systemized in a corresponding way. In certain fields in which typology is applied, such as engineering sciences, it is well know from the experience that the criteria of such typology are numerically measurable. However, when typology is applied in social and related sciences, then the circumstances are quite different, as there are no generally accepted objective points of reference on the basis of which it can be determined which criteria are measurable and which ones are not. In such situations there comes subjective strategy of the author which is beyond domain of the exact data. ${ }^{21}$ 
Studying measurability of typological criteria, R. Tomovic indicates the existence of "solid" and "soft" systems whereby with "solid" systems the processes are described as a set of measurable criteria, whereas with the "soft" systems there appear also immeasurable criteria in a great number, which significantly makes the research procedure difficult. For that purpose he proposes arrangement of criteria along one spectrum, so that at one end there are criteria with extremely measurable characteristics and at the other end the immeasurable criteria. In that way a whole series of overflows is obtained indicating to greater or lesser presence of measurable namely immeasurable criteria. ${ }^{22}$

When it concerns the significance and number of relevant criteria, each typology is based on a series of limitations. Primarily, the number of criteria must be reduced down to a reasonable measure, so that the number of types would be limited to an easy-to-survey number. By introducing a great number of criteria, the number of types is increased which makes classification badly laid out and unusable. Besides, the number of possibilities within a single criterion must also be limited for the same reason. Finally, all criteria need not always be of equal significance so that in such situations it is necessary to introduce certain hierarchy which would determine the significance of criteria.

One of the basic problems when selecting criteria for typological classification could be the tendency of over-stressing those characteristics of individual cases which are mutual, i.e. to ignore those ones which separate the individual cases. In that case a problem arises which can be manifested in two ways. First, by existence of criteria which limit defining of groups, second, by including namely excluding individual cases from the formed groups on the grounds that they correspond to criteria of two or even more types.

The instinct for typology can be considered as a natural characteristic of human behavior. Human beings create and follow personal stereotypes in order to recognize the things, distinguish danger from friendly behavior, or in order to recognize the space they occupy. Only, the criteria used in typology are not the same with all persons. They depend on each individual culture and experience.

The basic function of each typology is to identify, simplify, limit through selection and place in order the data and phenomena, with the goal of having manifestations and processes considered as typical compatible and representative (process repetitive) ones. In its essence type possesses a hypothetical character and offers extraordinary possibilities for predicting the 
future development, for if there are some typical patterns, it is likely that the typical consequences will be manifested.

Max Weber has particularly emphasized that none of the types of some social manifestation can ever be found in the ideal or solid form because "in its conceptual purity this contemplative statement cannot be found empirically anywhere in reality. It is utopia. "23

According to Mc Kinney the entire process of types forming consists of the following stages: the first one, in which observation of regularity within some area or process is developed and initially constructed type is created; the second one, representing breaking down of types, where a set of criteria out of which types are derived is formulated; the third one, which is analytical and in which data are collected and processed; the fourth one, which can be named also the discriminatory one as it comprises reduction of criteria; the fifth one, in which comparison of the initial and empirical criteria is carried out. It is in the last stage that transition of the constructed types from the initial stage through data is actually carried out and also their return back in order to ascertain their representative quality. In that sense, Mc Kinney calls attention to the danger of premature "freezing" of types and premature declaration into types. ${ }^{24}$

The successful typology is considered to be the one in which all elements of the system are classified in such manner that nothing needs to be added (would be superfluous) and nothing needs to be taken out (by exclusion of key elements would degrade the system). The basic endeavor of typology is to place the disputable and seemingly invincible elements into the system.

\section{Character of Typological Research in Architecture and Urbanism}

General principles related to typological classification as discipline are valid with typology both in architecture and urbanism. However, typology as the way of analyzing development of individual forms in architecture and urbanism has some of its own specific features. They primarily refer to the basic elements and entities which architecture and urbanism deal with, and that is buildings and open spaces. On the other hand, typological approach applied to the fields of architecture and urbanism makes it possible for these fields to become imbued with other aspects related to society development.

In the historical dictionary of architecture Katrmer de Kinsi defines the concept of type in architecture quite precisely, so that his definition has not in the least 
lost any of its actualities: "In each country the art of building is usually developed from one preembryo. It is necessary that there was a predecessor, there is not a thing that arises from out of nothing, not in any field, so that we cannot help but apply this to all human inventions. Thus we can see that even despite later changes all of them have preserved the basic principle, which is always clear and recognizable to the feelings and intellect. That principle is like a core around which the developing variant forms then, which it was an object to, accumulated and harmonized. Therefore, we have been reached by thousands of things in all forms, and one of the major preoccupations of science and philosophy is determining of the reason of creation of those things as well as the research into their origin and initial cause. That is which should be called a "type" in architecture as well as in any other branch of inventions and human institutions. ${ }^{25}$

Aldo Rossi was particularly engaged in typology of architectural and urban elements, who understood type as the idea of architecture itself, i.e. that which is the closest to its essence and that which is imposed to be comprehended as the principle of architecture. According to Rossi "typology thus becomes analytical moment of architecture, and can even better be perceived on the level of urban entities. ${ }^{26}$ The significance of typology within urban entities points out to the fact that the structure of the complex urban form can only be correctly studied and systemized by means of typological classification.

Christian Norberg-Schulz, among others, has been engaged in the phenomenon of typology of urban entities, who even though asking the question "... whether it was possible to establish typology of urban spaces...", ${ }^{27}$ immediately thereafter explains the criteria on the basis of which it could be formed. According to him, typological classification of urban entities should be based on functional and formal aspects, or on their combination. ${ }^{28}$ Norberg-Schulz has stated that any urban entity can be and should be observed through three integral and interdependent elements of the language of architecture: morphology, topology and typology, about which he says: “...morphology concerns the "how" the form has been built and in the individual architectural part it is presented as "formal articulation" ... topology deals with spatial order and in the individual builder portion it is exposed as "spatial organization". The expression topology has been selected in order to show that architectural space originates from the place (topos) rather than from an abstract mathematical space... typology indicates that places are one endless multitude of essentially different cases, but that they form the universe of figurative identities... ". ${ }^{29}$ 
"The Third Typology" by Anthony Vidler, is probably one of the most significant texts explicitly written on typology in architecture. Vidler believes that traditional architectural production is based on the two existing typologies. The first one, originating from the natural roots of architecture, (the concept of the primitive hut), and the second one, brought about by the industrial revolution, where architecture emerged as a logical consequence of mechanical production. Vidler believes that these two existing typologies need to be added the third one to. The third typology, as well as the former two ones are clearly based on the reason, classification and purpose of architecture, however, as different from the first two ones it does not prescribe general remedy for all, does not give preferential treatment to maximal worship of man in architecture and does not strive towards positive extremeness. ${ }^{30}$

Typologies within the field of architecture and urbanism are an important mean which serve the professionals to recognize the differences and to establish precise space codes. They occur as a lucky combination of principle of individualization and principle of classification. In the best case they can lead to revelation of "generic code", consisting of key development characteristics in specific space. Such types serve as mental characters which can express an idea or can be compared to the other spatial types. In any case, in the designing and planning process the types do not present strict rules, but only the frameworks for different variations.

\section{TYPOLOGY IN PARCIPATION WITH MORPHOLOGY}

The subject of typology in architecture and urbanism has been classified by means of studying architectural and urban elements, with the goal of noticing, singling out and grouping of the examples that have common characteristics, in order to classify them in a certain type. Naturally, it does not only concern making the inventory of common characteristics, but the very essence of those characteristics is researched. The subject of typology need not be related only to defining of individual types, but also to the relations governing among them. In this field the relation between architectural typology and urban morphology represents the mostly layered and the most complex form of typological classification, and is expressed within the domain of typo-morphology.

The comprehensiveness of typo-morphology is reflected in its complexity and ability to simultaneously define physical and spatial structure of the city. Typomorphology is a complex discipline dealing with the research of urban forms on the basis of study of the types of spaces and buildings. The architects and 
planners engaged in typo-morphology consider that it can be defined as "operationalized history of form" as it registers all professional and amateurish activities which during a longer period of time had forming of cities as a result. Typo-morphological approach to the research of architectural and urban forms differs from other methods in three ways: first, the type applied in typomorphology combines characteristics of the buildings with the open spaces corresponding to them; second, by inclusion land as a constituent element in the typology of form it becomes a link between individual elements and wider urban context; three, the buildings and open spaces are not observed only as the current condition within the space, but in morphogenetic way meaning the time during which the city has formed, developed and changed. ${ }^{31}$

Typo-morphological researches in Italian land have their roots in the researches made by Savero Muratori, who, together with his immediate successor Gianfranco Caniggia, analyzing the processes of construction of traditional Italian cities formed the theory for designing of new cities. ${ }^{32}$ In his work Muratori has always emphasized two facts: first that the structure of the city can be comprehended only within historical continuity, and second, that typology of constructed forms is the basis for urban forms analysis. The buildings and their non-constructed environment make the urban form which is the result of numerous ideas, actions and activities being imbued, and together can be classified in the types by means of which the essence of their diverse character can be shown. The common approach of their research was directed towards uncovering of genetic spatial code, which can be preserved and developed. According to their interpretations, typology and urban morphology, particularly the aspects of historical development, present the required prerequisites for successful designing.

As different from Italy where the holders of ideas on typo-morphology were exclusively architects, in France, besides architects there were planners, geographers, sociologists, historians who were equally interested in this discipline. For that reason typo-morphological researches in France do not comprise only the researches of urban form but also extensive social studies. The initiator of typo-morphological researches in France can be considered to have been Henri Lefebre, who had a critical attitude towards modern theory of architecture and urbanism which had preferred mass housing construction without caring for urban landscape. His works have immediately influenced the three authors, Jean Castex, the architect, Phillippe Panera, the town planner and Jean-Charles Depaule, the sociologist, the members of Versaille typomorphological school, who have left behind the greatest contribution to the study of typo-morphology in France. ${ }^{33}$ In their works the relations between 
constructed and social space are shown as dialectical. The authors believe that the constructed space is independent from the social space, and that physical space can be described and used by the people in their everyday life. Physical space has its own logics which becomes real and is purposeful only through social actions. The members of the Versaille school believe that the roots of architecture should be discovered anew in the past traditions and that such experience should be used as a recovery from the deserted cultural context arising from the Modern movement.

The founder of the typo-morphological research in England is considered to be M.R.G. Conzen, the geographer and town planner, who based his researches on the analysis of three components: city plan (as a cartographic manifestation of the physical appearance of the city), city tissue (as the set of buildings and open spaces) and the manner of use of the buildings and land (as the detailed land use plan). ${ }^{34}$ In 1980, Conzen's followers founded the Urban Morphology Research Group at the University of Birmingham. The Group consisted of the experts within various fields the common goal of whom was determining of transformation of building forms due to the change in the existing type or for the purpose of generation of the new type. The result of their work was also a glossary of terms which Conzen used in his morphological researches. The Urban Morphology Research Group had an emphasized morphogenic approach, because they based their research not only on the existing city structure but also on its time dimension, namely transformation. Their researches were based on the modern morphological principles of multicultural comparison. This approach combines the researches of city spatial structures and their morphogenic process in different cultural and political conditions.

The common characteristic of all the three typo-morphological approaches (the Italian, the French and the English ones) is reflected in the fact that they observe the city landscape through time, form and size. City space is undergoing continuous process of changes under the influence of social and economic conditions of building, use and transformation of space. For that reason it is only correct to observe it through time namely within the frame of the stages during which it experienced certain changes, as believed by the representatives of all three typo-morphological approaches.

Besides exceptional significance of typological studies, it is difficult to bring into line and identify morphological and typological researches, primarily for the reason that types and typology are used in researches of some morphologies. Apart from that, the level of complexity and differentiation in researches of individual types cannot be comparable to the morphological one. One type 
covers one characteristic in spatial sense, whereas morphology deals with systematic research of the form within the domain of its origin, growth and function, combining various levels and scales.

Contrary to morphology, the concept of architectural and urban typology is based on spatial elements which are organized into certain entities. These entities are physically distinguishable and are classified on the basis of key characteristics. Methodologically, typological researches follow one line, taking care of one spatial entity and one level of function. In the course of the research they should be singled out in relation to other types, spatial entities and functions. However, the development of one type can be followed through comparison with the entities of the same function, from the different period and different culture. ${ }^{35}$

Finally, the concept of type appears as the researcher slogan which could help in recognizing the characteristics and principles of the buildings and spatial entities. In practice, the knowledge can be used as an inspiration for planning and designing or as criterion for evaluation. Namely, the idea of typomorphology clearly reflects the fact that morphology and typology cannot be separated, nor that one concept can be dominant in relation to the other one. Actually, precise evaluation of each spatial configuration requires alternation and final synthesis of both concepts.

\section{CONCLUSION}

Many contemporary critics and theoreticians think that typology in architecture and urbanism cannot have great value. To some extent they are right, as the work cannot be valued according to which extent as per its characteristics it has come close to the ideal type. However, the ideal type is only an abstraction. For that reason it is unacceptable to form the type which is recommended as a standard according to which a certain work would be valued. The type does not present the image of something that should be imitated or copied, but that something according to which the different authors can create their works without the obvious mutual similarities. Within that context, those who consider typology as having no values, are not right.

Typology may not be the decisive factor of a creative process, however, it is always evident, even though its presence is not always transparent. Those critics who acknowledge that the types possess certain value are the ones who explain architectural forms in relation with symbolism. The main problem between typology and creativity is reflected in the question: does the symbolic 
context exist before creation of the type and whether that determines it or it is only the further consequence? When the symbolic function precedes the type and determines it this function has been filtered through certain architectural forms. In the same manner, when the opposite happens, the consequence of the form is the survey of the symbolic function in more or less conscious manner. The conclusion has to be that the typological and inventive aspects of the creative process are continual and linked. The inventive aspect is the one which deals with the requirements of the actual situation, by criticizing and overcoming certain solutions that have been incorporated in the type.

Even though each classification results from certain value determination which in some cases could be the dominant one, it should be emphasized that the goal of typology has not been directed towards valorization on the basis of formed parameters. Such attempt would certainly require a corresponding degree of formulation of the valuation system, which is not the subject of typology. It concerns here the wish to indicate the existence of certain principles contributing to some space to be identifiable and based on the procedures and models used by forming the city spaces. In that respect, the degree of coincidence of certain characteristics need not simultaneously present the quality of a given space.

Any classification should not be taken too rigidly, but should rather be observed as a process which continually develops and changes. It represents only one's standpoint towards a certain issue, which as any other standpoint is subject to analysis, criticism and revision. The moment the typological classification is accepted as something final and unchangeable the profound crisis for the matter classified begins. For that reason the typology should be observed as a contemporary auxiliary instrument which has to be flexible and open to new and different opinions, and not as a limitation which would interfere with future contemplations and actions.

NOTES

1
In biology, morphology is considered a special branch dealing with the research of forms and structure of living beings. Opšta enciklopedija Larousse in 3 volumes, Volume 1, (Belgrade, Vuk Karadžić - Intereksport, 1971), p. 575.

In linguistics, morphology is considered being part of the science on language studying the structure and form of the word. Morphological language classification is based on the use of various forms of certain words. According to morphological classification the languages are usually classified into: agglutinative, flexive, incorporative, analytical ones. Nova enciklopedija u boji Vuk Karadžić Larousse, (Beograd: Vuk Karadžić, 1977), p. 1199.

Morphology of history emerges as philosophical learning on various basic forms, changes and complexes of history. According to that learning in the heart of the entire historical event there are some pre-forms namely notions which make the foundation to all that is organic, such as notions of birth, death, youth, mature age and old age. Filozofija: Enciklopedijski leksikom - Mozaik znanja (Beograd: Interpres, 1973), p. 318.

One of the founders of modern sociology, Emil Durkheim, based social morphology as the study which relates to material form of society, i.e. to the number and nature of their parts, to the manner in which they are distributed on the surface of the Earth, to the internal migrations from one 
country to another, a form of agglomeration, dwelling, etc. He and his followers call it the science which studies the material society substratum, not only in order to describe it, but to explain it as well, i.e. the form which they acquire having settled on the certain land, scope and density of population, manner of their distribution etc. Sreten Vujović, ed. Sociologija Grada, (Beograd, Zavod za udžbenike i nastavna sredstva, 1988), pp. 68-76.

Morphology of culture appears as observation of certain cultures analogous to the forms of organic life. Cultural complexes are understood either as manifestation of certain spirit of the culture or as forms of development of individual mutually independent cultures, so that a conclusion could be derived on the future of modern cultures. Morphology of culture is linked to the German philosopher Oswald Spengler, according to whom each culture develops completely independently from all other cultures, according to quasi-biological laws and cyclic pattern analogous to the cycle of human life. Filozofija: Enciklopedijski leksikon-Mozaik znanja, p. 318.

Physical geography is a branch of geography which is made of geomorphology, hydrology, cryology, geochemistry, etc. Geomorphology is a branch of physical geography dealing with the study of the origin and development of the relief form on the Earth surface. Nova enciklopedija $u$ boji Vuk Karadžić - Larousse, (Beograd: Vuk Karadžić, 1977), p. 406.

Urban geography is a geographic scientific discipline which forms the aspect of interaction of the elements of natural base and social factors, studies and explains the phenomenon and spatial expansion of the cities, their form, functional and social structure as well as the significance and influence of the cities in space. Urban geography studies the city from its functional, demographic and morphological standpoint. Morphological aspect of the city ii reflected in the form and structure and relation of the elements it consists of. Milan Vresk, Osnove urbane geografije, (Zagreb: Školska knjiga, 1986), p. 2.

Defining geomorphology as the science studying the relief of the Erath surface which emerged due to the action of the internal terrestrial and solar forces, Cvijic pays great attention to the basic classification of the forms on the Earth's surface. Thus all kinds of forms on the Earth's surface are classified by him into two main groups: tectonic forms and erosive forms, whereas while expanding the classification, he divided erosive forms into: the forms of marine erosion and the forms of fluvial erosion, etc. Jovan Cvijić, Geomorfologija, (Beograd: Državna štamparija Kraljevine Srba, Hrvata i Slovenaca, 1924), pp. 1-10.

Vresk, p. 123.

R.E. Dickinson, "The Scope and Status of Urban Geography: An Assessment, in Readings in Urban geography (Chicago: University of Chicago press, 1959), pp. 10-26.

Non-controlled morphogenesis processes are those that occur beyond the control of the organized structures and without certain codified standards, unlike the controlled ones which are the result of various relations, and therefore the author additionally classified them into: interactive, simultaneous, active and expert ones. Miloš Bobić, Morfologija mesta, trinaest eseja o arhitekturi, (Amsterdam - Beograd - rukopis, 1990-1993) pp. 101-105. deutschen Landeskunde. Vol. 63 (1952), Vol. 74 (1953). Art, (New York: Princeton Architectural Press, 1992).

Aldo Rossi, Arhitktura grada, (Beograd: Gradjevinska knjiga, 1996).

Robert Krier, Urban Space, (London: Academy Editions, 1979).

Leon Krier, "The Reconstruction of the European City" in Rational Architecture, Archives d'Architecture Moderne, Bruxelels, 1978.

Besides Seaside, Andres Duany and Elizabeth Plater-Zyberk have prepared the plans for another over forty cities, including: Kentlands in Maryland, Blount Springs in Alabama, Charleston Place and Avalon Park in Florida, Mashpee Commons at Cape Cod. Besides plans for the new cities they have prepared also the designs for certain city boroughs out of which the best known are Playa 
Vista in Los Angeles and Daniel Island in Charleston. Andres Duany, Elizabeth Plater Zyberk, Chester E. Chellman, "New Town Ordinances and Codes" in New Classicism, Omnibus Volume, (New York: Rizolli, 1990), pp. 239-243.

Human intelligence, for example, is measurable and by measuring it IQ value is obtained coefficient of intelligence in five groups, which presents an example of quantitative classification. However, human temperament is immeasurable, however, can be classified into: sanguine, phlegmatic, choleric and melancholic, which presents an example of qualitative classification. Miroslav Zivković, Uvod u metodologiju naučnog istraživanja, (Belgrade: Arhitektonski fakultet, 1984), pp. 16-17.

Marina Todorović, Osnove tipologije i regionalizacije poljoprivrede Srbije, (Belgrade: Srpsko geografsko društvo, 2002), p. 25.

R. Tomović, "Osnove matematičkog modeliranja sistema", u Dijalektika, No. 2-3, Belgrade, (1978) pp. 22-26.

Max Weber. Ideal Types and Theory Construction. (New York: Brodbeck Readings in the Phil. Of Social Science, 1968) p. 497.

J. Mc Kinney, „Typification, Typology and Sociological Theory”. Social Forces, Vol. 48, (1969), pp. 1-12.

Rosi, p. 29.

Rossi, p. 30.

Norberg-Schulz, Stanovanje, stanište, urbani prostor, kuća, (Belgrade: Gradjevinska knjiga, 1990), p. 66.

Norberg-Schulz, p. 66.

Norberg-Schulz. pp. 25-29.

Anthony Vidler, “The Third Typology”, Designing Cities: Critical Readings in Urban Design, (Malden: Blackwell, 2003): pp. 317-322.

Nadja Kurtović Folić, “Tipomorfologija - otkrivanje fizičke i prostorne strukture grada”, DaNS, No. 15 (1995).

Saverio Muratori, Studi per una operante storia urbana di Venezia, (Roma: Instituto Poligrafico dello Stato, 1959). knjiga, 1989). 
Argan, Giulio Carlo. "On the Typology of Architecture". Theorizing a New Agenda for Architecture: An Anthology of Architectural Theory 1965-1995. New York: Princeton Architectural Press, (1996): 242-246.

Bobić, Miloš. Morfologija mesta, trinaest eseja o arhitekturi. Rukopis. Amsterdam - Beograd: 1990-1993.

---. Between the Edges: Street-building transition as urbanity interface. Bussum: Thoth Publishers, 2004.

Castex, Jean, Jean-Charles Depaule and Philippe Panerai, Urbane Forme. Beograd: Građevinska knjiga, 1989.

Conzen, M.R.G. "The use of Town Plans in the Study of History", The Study of urban History. New York: St. Martin's Press, (1968): 114-130.

Cuthbert, Alexander. The Form of the Cities: Political Ecconomy and Urban Design. Malden: Blackwell, 2006.

Cvijić, Jovan. Balkansko poluostrvo i južnoslovenske zemlje I, II. Beograd: Državna štamparija Kraljevine Srba, Hrvata i Slovenaca, 1922. 
Duany, Andres, Elizabeth Plater Zyberk and Chester E. Chellman. "New Town Ordinances and Codes”. New Classicism: Omnibus Volume. London: Academy Editions, (1990): 239-243.

Djokić, Vladan. Urbana morfologija: grad i gradski trg. Beograd: Arhitektonski fakultet Univerziteta u Beogradu, 2004.

Hegemann, Werner., and Elbert Peets. The American Vitruvius: An Architects' Handbook of Civic Art. New York: Princeton Architectural Press, 1988. (1922).

Krier, Leon. "Urban Components”. New Classicism: Omnibus Volume. London: Academy Editions, (1990): 197-203.

Krier, Rob. Urban Space. London: Academy Editions, 1979.

---. "Typological and Morphological Elements of the Concept of Urban Space". Designing Cities: Critical Readings in Urban Design. Malden: Blackwell, (2003): 323-339.

Kurtović-Folić, Nađa. "Tipomorfologija - otkrivanje fizičke i prostorne strukture grada". DaNS. br. 15, (1995): 37-39.

Mc Kinney, J. "Typification, Typoloogy and Sociological Theory". Social Forces Vol. 48. New York, (1969): 1-12.

Muratori, Saverio. Studi per una operante storia urbana di Venezia. Roma: Instituto Poligrafico dello Stato, 1959.

Rosi, Aldo. Arhitektura grada. Beograd: Građevinska knjiga, 1996.

Sitte, Camillo. City Planning According to Artistic Principles. Vienna: Verlag von Carl Graeser, 1889.

Stubben, Jozef. Der Stadtebau. Leipzig: 1924.

Todorović, Marina. Osnove tipologije i regionalizacije poljoprivrede Srbije. Beograd: Srpsko geografsko društvo, 2002.

Tomović, R. "Osnove matematičkog modeliranja sistema." Dijalektika, br 2-3, Beograd, 1978.

Vidler, Anthony. "The Third Typology". Designing Cities: Critical Readings in Urban Design. Malden: Blackwell, (2003): 317-322.

Weber, Max. Ideal Types and Theory Construction. Brodbeck Readings in the Phil. Of Social Science, p 497. New York, 1968. 